\title{
PEMBUATAN SURAT KETERANGAN WARIS OLEH NOTARIS BAGI MASYARAKAT ADAT BALI
}

\author{
Debiana Dewi Sudradjat \\ Fakultas Hukum, Universitas Katolik Parahyangan \\ email: d.dewi.sudrajat@unpar.ac.id
}

disampaikan 18/03/2020 - di-review 20/06/2020 - diterima 03/12/2020

DOI: $10.25123 /$ vej.3797

\begin{abstract}
The legal basis justifying the existence of notaries as public officials and a legal profession were Netherland-Indies laws. These colonial laws were, by virtue of Art. I Transitional Rules of the 1945 Constitution of the Republic of Indonesia (4th Amendment), taken over and considered to be still in force. Consequently, one of the public service offered by Notary publics, i.e., issuance of letter of inheritance or written affidavit stating which family members of the deceased may by law be regarded as heir-successor, has not been made available to Balinese adat communities. This service can only be enjoyed by those individuals who submit themselves to the (colonial) Civil Code. The article explores, using a juridical empirical approach, the possibility to extent the above public notary's service to Balinese adat (traditional) communities.
\end{abstract}

Keywords:

Written Statement of Successors, Heirs, Balinese adat communities, Notary Public

\begin{abstract}
Abstrak
Dasar hukum keberadaan Notaris sebagai pejabat publik, dan salah satu pengemban profesi hukum adalah peraturan perundang-undangan zaman Hindia Belanda yang diberlakukan berdasarkan pada Pasal I Aturan Peralihan Undang-Undang Dasar Negara Republik Indonesia Tahun 1945 Amandemen IV. Konsekuensi dari itu adalah salah satu layanan yang seharusnya diberikan Notaris, membuat Surat Keterangan Waris, hanya dapat diberikan pada mereka yang tunduk pada hukum perdata Barat. Layanan ini tidak tersedia bagi masyarakat adat Bali. Penelitian yuridisi empiris yang dilakukan menelusuri peluang dan celah-celah hukum yang terbuka agar layanan pembuatan surat keterangan waris juga dapat diberikan pada masyarakat adat Bali.
\end{abstract}

Kata kunci :

Surat Keterangan Waris, Masyarakat Adat Bali, Notaris Publik.

\section{Pendahuluan}

Penjajahan Belanda di Indonesia di masa lalu membawa dampak yang cukup besar bagi peraturan perundang-undangan di Indonesia. Pengaturanpengaturan di jaman penjajahan tersebut, saat ini masih menimbulkan kebingungan dalam praktik pelaksanaan hukum di Indonesia, terutama karena sekarang ini adanya kebutuhan masyarakat mengenai suatu pembaharuan hukum, sementara instrumen hukum yang ada belum mendukung adanya pembaharuan hukum tersebut. 
Dapat dikatakan bahwa induk permasalahan yang sesungguhnya, berawal dari dikeluarkannya Indische Staatsregeling (I.S), S. 1855-2 yang merupakan kelanjutan dari Reglement op het beleid der Regeering van Nederland Indie yang membedakan masyarakat Indonesia ke dalam 3 golongan penduduk. ${ }^{1}$ Penggolongan Penduduk masih dapat dirasakan relevansinya di jaman penjajahan Belanda karena adanya kepentingan-kepentingan tertentu dari Pemerintah Belanda sendiri, namun tidak demikian halnya dengan kehidupan Masyarakat Indonesia saat ini. Idealnya, seiring dengan kemerdekaan Indonesia, penggolongan penduduk tersebut seharusnya menjadi hilang, karena pada dasarnya warganegara Indonesia adalah satu dan seharusnya tidak ada penggolongan-penggolongan warganegara di dalamnya sebagaimana yang diatur dalam peraturan tersebut.

Apa yang kemudian kita temukan bahwa ternyata setelah jaman kemerdekaan, Pemerintah pernah membuat suatu peraturan untuk meniadakan penggolongan penduduk, namun penghapusan tersebut hanya ditujukan secara khusus dalam hal-hal yang menyangkut tentang Pencatatan Sipil. Dengan dikeluarkannya Instruksi Presiden No. 31/UI/IN/12/1966 pada tanggal 27 Desember 1966 mengenai Pencatatan Sipil tersebut, maka berakhirlah pengaplikasian Pasal 131 dan 163 IS dalam urusan pencatatan sipil, namun yang patut disayangkan bahwa penghapusan penggolongan penduduk ini hanya berhenti sampai di sini dan tidak dilakukan terhadap bidang-bidang lainnya.

Di dalam Masyarakat Indonesia sendiri, penggolongan penduduk masih diakui eksistensinya. Meskipun pandangan hidup masyarakat telah banyak mengalami pergeseran, namun pergeseran pandangan hidup dan kebutuhan masyarakat tidak dapat digunakan sebagai agen perubahan untuk melegalisasi kebutuhan akan adanya suatu peraturan yang berdiri atas semua golongan tanpa kecuali. Contoh yang paling konkrit adalah mengenai kebutuhan hampir seluruh masyarakat Indonesia dari golongan manapun juga terhadap surat-surat yang

1 C.F.G. Sunaryati Hartono, Dari Hukum Antar Golongan ke Hukum Antar Adat, Alumni, Bandung 1971, hlm., 5-6. 
berkaitan dengan keterangan waris, atau yang biasa dikenal sebagai Surat Keterangan Waris.

Hukum Indonesia saat ini masih membeda-bedakan pihak-pihak yang harus melayani pembuatan Surat Keterangan Waris tersebut. Bagi pihak-pihak yang tunduk pada Hukum Adat, kewenangan pembuatan Surat Keterangan Waris diserahkan kepada Pemuka/Kepala Adat sebagai pengganti Kepala Desa/Camat (khusus untuk masyarakat adat di beberapa tempat di Bali). Bagi pihak-pihak yang tunduk pada Hukum Islam, kewenangan pembuatan Surat Keterangan Waris diserahkan kepada Kepala Desa/Camat, dan bagi pihak-pihak yang tunduk pada Hukum Perdata Barat, Surat Keterangan Waris dibuat oleh Notaris.

Fokus perhatian berikutnya kita berikan pada masyarakat adat. Hukum Adat yang merupakan jiwa dari masyarakat adat telah sangat melekat dalam kehidupan mereka sehari-hari sehingga pelaksanaan terhadap aturan-aturan adat tersebut hampir tidak perlu dipaksakan lagi. Kesadaran hukum masyarakat adat telah menjadi modal utama bagi pentaatan atas Hukum Adat itu sendiri. Seiring dengan berkembangnya kehidupan masyarakat adat, masalah pewarisan kemudian menjadi suatu hal yang cukup kompleks dan banyak sekali menimbulkan sengketa, terutama pada Masyarakat Adat Bali. Keberadaan dokumen-dokumen yang dapat memberikan kepastian hukum bagi para ahli waris dalam Masyarakat Adat Bali serta dokumen yang dapat merealisasikan pernyataan keinginan terakhir seorang pewaris menjadi suatu kebutuhan yang tidak terelakkan lagi.

Praktik yang berlaku dalam masyarakat mulai memperlihatkan adanya perubahan karena kebutuhan dari pihak-pihak yang terlibat. Perubahan tersebut tampak dari adanya beberapa kasus yang ditemukan saat wawancara, dimana ditemukan bahwa adanya Masyarakat Adat Bali yang demi mendapatkan kepastian hukum, meminta Pihak Notaris untuk membuatkan Surat Keterangan Waris bagi keluarga yang ditinggalkan oleh pihak pewaris. Perubahan yang terjadi 
karena kebutuhan masyarakat tersebut akhirnya banyak menimbulkan pertanyaan mengenai pihak-pihak yang dapat dilayani oleh seorang Notaris. ${ }^{2}$

Notaris sendiri pada mulanya merupakan profesi yang dikenal dalam Hukum Belanda dan keberadaannya pada saat ini masih diakui berdasarkan Pasal II Aturan Peralihan Undang-Undang Dasar Negara Republik Indonesia Tahun 1945, yang pada saat ini telah dimasukkan ke dalam Pasal I Aturan Peralihan Amandemen ke-4 Undang-Undang Dasar Negara Republik Indonesia Tahun 1945. Pengertian tentang Notaris pertama kali dapat ditemukan pada Article 1 Notariswet (S.1860-3). ${ }^{3}$ Pengertian Notaris tersebut diadopsi langsung oleh Peraturan Jabatan Notaris di Indonesia yang mulai berlaku pada tanggal 1 Juli 1860 yang diterjemahkan ke dalam bahasa Indonesia. ${ }^{4}$

Selanjutnya dengan diberlakukannya Undang-undang Nomor 30 Tahun 2004 sebagaimana telah diubah dengan Undang-undang Nomor 2 Tahun 2014 tentang Jabatan Notaris (selanjutnya disebut dengan UUJN) maka definisi Notaris yang kemudian digunakan adalah sebagaimana yang diatur dalam dalam pasal 1 angka 1 UUJN. ${ }^{5}$ Dalam tugasnya, Notaris berwenang untuk membuat akta otentik.

2 Wawancara dilakukan dua kali yaitu pada bulan Juli tahun 2009 dan bulan Oktober tahun 2014 dan wawancara dilakukan dengan I Made Wira selaku Mantan Bendesa Adat terlama di Desa Adat Sampalan Bali, I Wayan Merta selaku Hakim di Pengadilan Negeri Denpasar Bali, Komang Bayu Baruna selaku generasi muda Masyarakat Adat Bali yang berpendidikan tinggi dan menjadi pegawai negeri, I Wayan Suata selaku Kepala Kantor Badan Pertanahan Nasional Kabupaten Jembrana, I Made Arya Sanjaya selaku Kepala Kantor Badan Pertanahan Nasional Kabupaten Klungkung dan Ida Ayu Ambarwati selaku Staff Kantor Badan Pertanahan Nasional Kabupaten Klungkung, I Ngurah Pariatna (yang pada saat wawancara diwakili oleh I Made Adnyana) selaku Kepala Kantor Badan Pertanahan Nasional Kota Denpasar, Ida Bagus Kd. Made Widiana selaku Klian Dinas di Kabupaten Jembrana, I Made Jati selaku Klian Dinas di Kabupaten Klungkung dan I Wayan Gunatra selaku Klian Dinas di Kabupaten Karang Asem

3 Reglement op Het Notaris-Ambt in Indonesia, Ordonantie van 11 Januari 1860, S.1860-3, bunyi asli pasal ini telah diterjemahkan langsung dalam Peraturan Jabatan Notaris di Indonesia sebagaimana yang akan disebutkan di bawah ini.

4 Peraturan Jabatan Notaris di Indonesia, Ordonansi S.1860 no. 3, dimana di dalamnya dinyatakan tentang pengertian Notaris, yang berbunyi: Para Notaris adalah pejabat-pejabat umum, khususnya berwenang untuk membuat akta-akta otentik mengenai semua perbuatan, persetujuan dan ketetapan-ketetapan, yang untuk itu diperintahkan oleh suatu undangundang umum atau yang dikehendaki oleh orang-orang yang berkepentingan, yang akan terbukti dengan tulisan otentik, menjamin hari dan tanggalnya, menyimpan akta-akta dan mengeluarkan grosse-grosse, salinan-salinan dan kutipan-kutipannya; semuanya itu sejauh pembuatan akta-akta tersebut oleh suatu undang-undang umum tidak juga ditugaskan atau diserahkan kepada pejabat-pejabat atau orang-orang lain.

5 UUJN juga mengatur tentang pengertian Notaris di Pasal 1 angka 1, yang berbunyi: Notaris merupakan pejabat umum, yang berwenang untuk membuat akta otentik dan memiliki 
Pengertian tentang akta otentik sendiri diatur dalam Pasal 1868 Kitab UndangUndang Hukum Perdata (selanjutnya disebut KUH.Perdata). ${ }^{6}$ Salah satu akta otentik yang merupakan kewenangan Notaris adalah Surat Keterangan Waris.

Berawal dari adanya kebutuhan masyarakat mengenai adanya terobosan baru dalam perundang-undangan Indonesia dan keinginan untuk mengajukan sebuah wacana berpikir baru bagi kalangan Pembuat Peraturan Perundangundangan dan para Notaris, Penulis telah melaksanakan suatu penelitian mengenai problematika yang timbul dalam proses pewarisan adat di Bali serta dampaknya terhadap tugas seorang Notaris sebagai pejabat umum pembuat akta otentik terutama Surat Keterangan Waris.

Untuk dapat menjawab persoalan-persoalan yang timbul dalam Masyarakat Adat Bali, maka penulis akan menggunakan metode pendekatan yuridis-empiris, di mana penulis mengadakan survei literatur dan peraturan perundang-undangan sekaligus mengadakan observasi lapangan, termasuk di dalamnya mengadakan wawancara atas beberapa pihak yang dianggap kompeten dan cukup mumpuni dalam memberikan keterangan sehubungan dengan penelitian ini. Hasil telaahnya diharapkan dapat memberikan solusi bagi Masyarakat Adat Bali secara khusus dan juga menjadi sumbangsih yang berarti bagi masyarakat adat di seluruh Indonesia.

Berdasarkan hal yang telah dipaparkan dalam latar belakang di atas, ditengarai bahwa, masalah-masalah yang timbul dalam Masyarakat Adat Bali tersebut antara lain: Dengan melihat kondisi perundang-undangan di Negara Indonesia saat ini, apakah seorang Notaris dimungkinkan untuk membuat Surat Keterangan Waris bagi masyarakat adat Bali?, dan sejauhmana kebutuhan

kewenangan lainnya sebagaimana dimaksud dalam Undang-Undang ini atau berdasarkan Undang-Undang lainnya.

6 Pasal 1868 KUH.Perdata menyatakan tentang definisi akta autentik, dalam bunyi aslinya adalah sebagai berikut: "Eene authentieke acteis de zoodanigewelkein de wettelijken vorn is verleden, door of tenoverstaan van openbareambtenaren die daartoe bevoegd zijn ter plaatsealwaar zuiks is geschied." Yang kurang lebih jika diterjemahkan sebagaimana yang ternyata dalam KUH Perdata yang digunakan di Indonesia adalah sebagai berikut: suatu akta otentik ialah suatu akta yang dibuat dalam bentuk yang ditentukan Undang-Undang oleh atau di hadapan pegawai-pegawai umum yang berkuasa untuk itu, di tempat dimana akta itu dibuat. 
masyarakat akan suatu tindakan hukum dapat mendorong dibuatnya Undangundang yang dapat memenuhi kebutuhan hukum masyarakat tanpa mengenal golongan pada masa pasca kemerdekaan Indonesia?, dan jalan keluar apakah yang diperlukan oleh negara ini sehingga kebutuhan seluruh masyarakatnya terhadap suatu Surat Keterangan Waris dapat terpenuhi secara optimal dan legal?

\section{Pembahasan}

\section{Kajian Pustaka}

Penggolongan penduduk di Indonesia berawal dari jaman penjajahan Belanda di Indonesia. Strategi memisahkan penduduk Indonesia dalam beberapa golongan merupakan strategi jitu yang digunakan pemerintahan Belanda dalam rangka mengadu domba masyarakat Indonesia. Politik pemecah belah masyarakat Indonesia yang dikenal sebagai politik devide et impera merupakan politik yang membagi masyarakat Indonesia ke dalam 3 (tiga) golongan penduduk, yaitu Golongan Eropa, Golongan Timur Asing (seperti Tionghoa, India, Arab dan Pakistan) dan Golongan Pribumi sebagaimana diatur dalam Pasal 163 IS.7 Pembedaan golongan yang dibuat oleh Pemerintah Belanda saat itu, membawa dampak pada pemberlakuan sistem hukum yang berbeda bagi setiap golongan yang ada sebagaimana diatur dalam Pasal 131 IS. $^{8}$

Pengaturan pembagian golongan yang dibuat oleh Pasal 163 IS adalah sebagai berikut: ${ }^{9}$

a. Golongan Eropa, terdiri dari:

- Seluruh Bangsa Belanda

- Seluruh Bangsa Eropa yang Non-Belanda

- Seluruh Bangsa Jepang (berdasarkan perjanjian dagang antara Belanda dengan Jepang tahun 1896 sebagaimana diatur dalam S.1898:49

- Seluruh bangsa dimana di negerinya diberlakukan hukum keluarga yang berasaskan sama dengan Hukum Keluarga Belanda

\footnotetext{
Supra note 1

Id

https://tommizhuo.wordpress.com/2014/11/22/alasan-penggolongan-pendudukpluralisme-hukum-dan-pengertian-penundukan-diri-dalam-hukum-perdata/ 11 Agustus 2015 $10: 26$
} 
- Anak-anak sah atau yang diakui menurut ketentuan Undang-undang pada 4 point diatas yang lahir di Hindia Belanda.

b. Golongan Bumiputera, yang terdiri dari seluruh orang asli dari Hindia Belanda (yang saat ini disebut sebagai Indonesia)

c. Golongan Timur Asing, yaitu semua orang yang bukan Golongan Eropa dan bukan Golongan Bumiputera. Golongan ini dibedakan menjadi Golongan Tionghoa dan Golongan Non-Tionghoa (seperti India, Arab, Afrika, Pakistan dan sebagainya).

Pembagian penduduk atas golongan-golongan di atas mengakibatkan perbedaan sistem hukum yang diberlakukan oleh Pemerintah Belanda bagi setiap golongan yang ada. Penggolongan penduduk yang dilakukan oleh Pemerintah Belanda pada masa Indische Staatsregeling (IS) berawal dari perubahan Grond Wet di Negeri Belanda pada tahun 1922. Pada masa berlakunya IS ini bangsa Indonesia sudah turut membentuk undang-undang dan turut menentukan nasib bangsanya karena mereka turut dalam volksraad. ${ }^{10}$ Pada pasal 131 IS dapat diketahui bahwa pemerintah Hindia Belanda membuka kemungkinan adanya usaha untuk unifikasi hukum bagi ketiga golongan penduduk Hindia Belanda pada waktu itu yang ditetapkan dalam pasal 163 IS. Namun demikian dalam hal Hukum Waris, Negara Indonesia memang masih menganut sistem hukum yang plural, dalam arti ada 3 sistem hukum yang "bermain" di dalamnya, yaitu Hukum Adat, Hukum Islam dan Hukum Perdata Barat. Berlakunya 3 sistem hukum tersebut sebagaimana yang telah dijelaskan di atas membuat adanya 3 macam petugas yang berperan dalam pembuatan Surat Keterangan Waris.

Dalam Masyarakat Adat Bali, tidak dikenal adanya pemberian waris ketika pewaris masih hidup. Dalam Hukum Waris Adat Bali, terbukanya suatu warisan dapat diberikan pengertian yang berbeda pada setiap daerah di Bali. Pada umumnya, suatu warisan sudah dapat dikatakan terbuka jika sang bapak telah meninggal dunia. Akan tetapi, ada juga beberapa wilayah tertentu yang menganggap bahwa, suatu warisan baru dapat dikatakan terbuka apabila pewaris

10 http://ikhsanm.blogspot.com/2011/06/tata-hukum-atau-sejarah-tata-hukum-pada.html 12 Agustus 2015, diakses tgl 18 November 2016 pukul 20:49. 
(laki-laki/bapak), dan pasangannya (perempuan/ibu) kedua-duanya telah meninggal dunia. ${ }^{11}$

Pengertian Harta Warisan juga dikenal dengan istilah yang berbeda-beda. Di beberapa daerah, pengertian harta warisan dari yang meninggal dikenal dengan istilah peguna kaya ${ }^{12}$, namun ada juga yang menyebutnya sebagai kekodagan atau tetamian. Fakta yang tampak di dalam Masyarakat Adat Bali, memperlihatkan dikenalnya dua macam harta warisan yang dikelompokkan sesuai dengan cara pembagiannya, yaitu: ${ }^{13}$

a. Harta Warisan yang dapat dibagi. Harta warisan yang dapat dibagi, dikelompokkan lagi menjadi dua macam, yaitu:

1) Barang materiil, contohnya: tanah, pekarangan, sawah, rumah.

2) Barang imateriil, contohnya: hutang yang tidak dikecualikan, piutang serta kewajiban-kewajiban lainnya. Kewajiban-kewajiban lain yang dimaksud disini antara lain adalah: pengalihan tanggung jawab atas kewajiban pihak pewaris ke Desa Adat dimana pewaris tersebut pernah tinggal. Kewajiban-kewajiban selaku warga Desa Adat antara lain meliputi kewajiban atas kegiatan matur piuning dan mepejati ngaturan bhakti pemungkah, yaitu merupakan kegiatankegiatan pendahuluan berupa doa-doa, sajen dan permohonan restu lainnya kepada Sang Hyang Widhi Wasa yang wajib dilakukan untuk mengawali pembangunan-pembangunan yang akan dilakukan di Desa Adat tersebut.

b. Harta warisan yang tidak dapat dibagi.

1) Barang yang disakralkan, seperti: keris, pusaka.

2) Bangunan keagamaan, seperti: sanggah, merajan. Dalam hal ini yang diwariskan adalah sanggah yang menjadi tanggung jawab pihak pewaris. Pemeliharaan atas sanggah tersebut secara otomatis akan berpindah kepada pihak penerima harta tetap berupa tanah dan bangunan dimana sanggah tersebut berdiri."

Setelah bicara mengenai saat terbukanya warisan dan objek warisan, maka kita melangkah lebih lanjut pada pihak-pihak yang berhak mewaris dan pengecualian yang dikenal dalam hak mewaris di dalam Hukum Waris Adat Bali.

11 Tim Penelitian dan Penulisan Hukum Adat Waris, Penelitian Hukum Adat tentang Warisan di Wilayah Hukum Pengadilan Tinggi Denpasar, Laporan Penelitian, Proyek Penelitian Hukum Adat Mahkamah Agung, 1990;

12 Bdk. I Gusti Ketut Kaler, Butir-butir Tercecer Tentang Adat Bali 1, Penerbit Bali Agung, Denpasar, 1983, hlm., 62.

13 I Made Suasthawa Dharmayudha dan I Wayan Koti Çantika, Filsafat Adat Bali 1, PT Upada Sastra, Denpasar, 1991, hlm., 9. 
Dalam masyarakat patrilineal dengan sistem pewarisan mayorat patrilineal seperti halnya di Bali, pihak-pihak yang dapat menjadi ahli waris adalah ${ }^{14}$ :

a. Anak kandung laki-laki maupun keturunan laki-laki dari anak laki-laki tersebut.

b. Anak perempuan yang diangkat sebagai "sentana rajeg".

c. Anak angkat laki-laki yang telah diangkat sesuai dengan prosedur tertentu yang telah ditetapkan oleh adat, yang dikenal dengan upacara peperasan.

d. Anak angkat perempuan yang telah diangkat sesuai dengan prosedur tertentu yang telah ditetapkan oleh adat, yang dikenal dengan upacara peperasan dan diangkat sebagai "sentana rajeg".

e. Kemenakan laki-laki jika ternyata pewaris tidak memiliki anak laki-laki dan tidak memiliki baik anak perempuan kandung atau anak perempuan angkat sah yang diangkat sebagai "sentana rajeg", maupun anak angkat laki-laki yang sah.

f. Saudara kandung laki-laki jika pewaris tidak memiliki keturunan sebagaimana yang disebutkan dalam point a sampai dengan e.

g. Saudara terdekat (dadia) jika tidak ditemukan lagi keturunanketurunan dalam garis ke bawah dari pewaris serta tidak ditemukan saudara kandung pewaris.

h. Warisan akan jatuh kepada Banjar/Desa jika ternyata sudah tidak ditemukan lagi ahli waris dari point a sampai dengan $\mathrm{g}$.

Pihak-pihak yang dikecualikan dalam pewarisan/kehilangan hak warisnya menurut masyarakat adat Bali, adalah ${ }^{15}$ :

a. Anak astra/hastra/anak bebinjat, yaitu anak yang lahir dari perkawinan yang tidak sah atau di luar perkawinan.

b. Anak tiri.

c. Anak yang dipecat dari posisi ahli waris karena telah melakukan perbuatan-perbuatan yang durhaka, seperti membunuh, mencoba membunuh dan perbuatan-perbuatan durhaka lainnya.

d. Anak yang pindah agama atau pindah kewarganegaraan.

e. Seorang anak diangkat menjadi anak angkat keluarga yang lain.

Masyarakat Adat Bali juga mengenal adanya pihak-pihak yang bukan ahli waris namun memiliki hak untuk menikmati warisan demi kehidupannya selama

\footnotetext{
14 Berdasarkan lembaran lepas dari Perpustakaan Daerah Bali yang diterima tanpa judul, tanpa pengarang, tanpa penerbit serta tanpa tahun penerbitan. 
ia memenuhi syarat yang ditetapkan oleh hukum waris adat Bali. Pihak-pihak tersebut adalah ${ }^{16}$ :

a. Seorang janda, selama ia belum menikah lagi dan menjalankan dharmanya sebagai seorang janda.

b. Anak perempuan yang belum menikah keluar.

c. Anak perempuan yang telah menikah keluar namun mulih daha.

Hal lain yang bersangkutan dengan pewarisan di Bali adalah tentang pemberian, hibah dan wasiat dalam Masyarakat Adat Bali. Sebetulnya tujuan dari pemberian atau hibah (sedikit berbeda dengan wasiat) pada Masyarakat Bali adalah lebih ditujukan untuk memberikan sesuatu kepada keturunannya yang dianggap bukan merupakan ahli waris, sehingga pemberian harta inipun diberikan di saat calon pewaris masih hidup. Pemberian harta kepada keturunan yang bukan merupakan ahli waris semasa calon pewaris masih hidup dikenal dengan berbagai sebutan. Setiap istilah yang dikenal sebagai pemberian, memiliki pengertian yang berbeda-beda. 17 Sebagai contoh, "bekel/ketipatan", yaitu pemberian lepas dari calon pewaris kepada keturunannya yang akan menikah keluar. "Bekel/ketipatan" diberikan dengan maksud sebagai bekal bagi keturunannya tersebut dalam menjalani kehidupan barunya karena sesuai dengan aturan Hukum Adat ia tidak berhak menerima warisan (semacam hibah dalam Hukum Perdata Barat) ${ }^{18}$. Penerima "jiwa dana" dalam Hukum Adat Bali misalnya adalah anak perempuan yang bukan merupakan "sentana rajeg". Selain anak perempuan yang bukan merupakan "sentana rajeg", seorang anak laki-laki yang menjalankan kawin nyentana atau kawin nyeburin pun tidak berhak mewaris dari keluarga asalnya. Dalam hal seorang anak laki-laki melakukan kawin nyentana atau kawin nyeburin, maka ia memenuhi klasifikasi untuk dapat digolongkan sebagai penerima "jiwa dana"19. Akan tetapi, seringkali hal ini dianggap merupakan aib bagi keluarga Bali, karena itu berarti walaupun keluarga ini memiliki anak laki-laki namun anak laki-laki tersebut tidak dapat memelihara

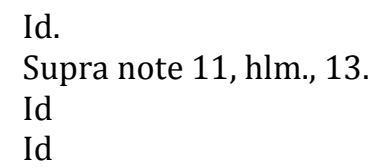


sanggah (tempat pemujaan) keluarganya dan malahan berkewajiban memelihara sanggah keluarga istrinya sehubungan dengan status baru yang dimilikinya akibat dari kawin nyentana tersebut. Oleh karena itu, jarang sekali ada keluarga yang mau memberikan "jiwa dana" kepada seorang anak laki-lakinya yang telah kawin nyentana/kawin keluar.

Dewasa ini, Masyarakat Adat Bali banyak menggunakan lembaga pemberian ini sebagai salah satu upaya untuk memenuhi rasa keadilan dan kewajiban bagi orang tua kepada anaknya yang dianggap bukan merupakan ahli waris.

Lembaga pemberian yang dikenal oleh Masyarakat Adat Bali antara lain terdiri dari ${ }^{20}$ :

a. Jiwa dana ${ }^{21}$ adalah pemberian kepada anak perempuan yang belum menikah.

b. Tetatadan adalah pemberian kepada anak perempuan pada saat menikah keluar dan diberikan sebagai hadiah.

c. Pengeling-eling adalah pemberian semasa pewaris hidup.

d. Pandum Poma/Pedum Pamong/Pedum Raksa adalah pemberian semasa pewaris hidup dan nantinya akan diperhitungkan sebagai harta warisan dalam boedel harta warisan.

e. Pangupa jiwa adalah pemberian yang hanya dapat untuk dinikmati dan bukan untuk dimiliki. Pangupa jiwa sebenarnya dapat dikatakan serupa dengan hak yang diberikan kepada seorang janda, anak perempuan yang belum menikah keluar atau anak perempuan yang telah menikah keluar namun mulih daha. Akan tetapi, bedanya adalah bahwa Pangupa jiwa merupakan hak yang dapat dinikmati semasa pewaris masih hidup sementara hak ini juga akan berlangsung terus bagi subjek yang sama jika si pemberi telah meninggal dunia.

f. Bekel/ketipatan adalah pemberian kepada anak perempuan yang kawin keluar. Pemberian ini akan menjadi harta bawaan yang akan dibawa oleh anak perempuan tersebut dan jika anak perempuan ini sampai bercerai dan mulih daha, maka harta ini harus kembali ke asalnya."

Setelah penulis memfokuskan pembahasan pada Hukum Waris Adat Bali, maka selanjutnya akan dilakukan pembahasan mengenai profesi notaris untuk mendapatkan jawaban-jawaban dari persoalan hukum yang ada. Lahirnya profesi notaris, diawali pada Jaman Romawi Kuno, yaitu sekitar Abad kedua dan ketiga

20 Supra no 14

21 Supra no 12, hlm., 63. 
Masehi. Pada awalnya, Bangsa Romawi Kuno mengenal suatu profesi yang disebut sebagai Scribae. ${ }^{22}$ Scribae sendiri merupakan seorang terpelajar yang memiliki tugas untuk mencatat nota dan minuta dalam suatu kegiatan atau keputusan untuk kemudian membuatkan salinan dokumennya, baik untuk dokumen privat maupun dokumen publik. ${ }^{23}$ Profesi Tabelliones dan tabularii, merupakan profesi yang dikenal juga oleh masyarakat Romawi. Kata Tabelliones sendiri diperkirakan diambil dari kata "tabulae" yang berarti plat berlapis lilin yang dipakai untuk menulis. Akta dan surat yang dibuat oleh para Tabelliones tidak memiliki kekuatan otentik sehingga akta-akta dan surat-surat tersebut hanya memiliki kekuatan seperti akta di bawah tangan. ${ }^{24}$ Profesi yang mirip dengan Tabelliones bahkan dapat dikatakan sebagai pesaingnya adalah profesi tabularii. ${ }^{25}$ Pengertian tabularii sendiri adalah seorang Tabelliones yang mempunyai keahlian dalam teknik menulis sehingga mereka diberikan status pegawai negeri yang mempunyai tugas mengadakan dan memelihara pembukuan kota dan menjaga arsip dari magistrat kota-kota yang berada di bawah ressort-nya. ${ }^{26}$

Indonesia mengadopsi sistem hukum sipil, yang artinya menganut mazhab Notaris Latin. ${ }^{27}$ Notaris di Indonesia memberikan legal advice kepada para pihak, sepanjang tidak bertentangan dengan Undang-undang yang berlaku, ketertiban dan kesusilaan. ${ }^{28}$ Mazhab Notaris Anglo Saxon mengatur bahwa Notaris Anglo Saxon hanya bertanggung jawab terhadap akurasi dan legalitas isi perjanjian akta. ${ }^{29}$ Oleh karena itu akta yang dihasilkan oleh Notaris Latin sangat diperhitungkan oleh Pengadilan karena merupakan bukti otentik sementara akta yang dihasilkan oleh Notaris Anglo Saxon tidak diperhitungkan sebagai alat bukti oleh Pengadilan. ${ }^{30}$ Secara filosofis, konsep dan praktik Sistem Kenotariatan Latin

\footnotetext{
Bdk. Pengurus Pusat Ikatan Notaris Indonesia, Jati Diri Notaris Indonesia, Dulu, Sekarang dan Di Masa Datang, PT Gramedia Pustaka, Jakarta, 2008, hlm., 40. 
dan Sistem Kenotariatan Anglo Saxon sangat berbeda. ${ }^{31}$ Perbedaan kedua sistem kenotariatan ini mengakibatkan hal ini perlu dipahami sepenuhnya sehingga tidak akan menimbulkan kerancuan yang pada akhirnya akan berdampak penurunan kualitas sistem hukum perdata di Indonesia. ${ }^{32}$

Indonesia sebagai Negara yang pernah dijajah Belanda, mengadopsi peraturan yang senada dengan peraturan kenotariatan Belanda (Notariswet) dan mengaplikasikannya ke dalam suatu aturan yang dinamakan Peraturan Jabatan Notaris dan mulai diberlakukan pada tanggal 1 Juli $1860 .{ }^{33}$ Peraturan Jabatan Notaris sebenarnya merupakan salinan dari pasal-pasal yang ada dalam Notariswet yang berlaku di negeri Belanda. ${ }^{34}$

Setelah Indonesia merdeka, pemerintah tidak segera mengembangkan konsep peraturan baru. ${ }^{35}$ Peraturan Jabatan Notaris masih tetap digunakan sebagai satu-satunya undang-undang yang mengatur masalah kenotariatan di Indonesia, sementara Notariswet sebagai aturan induknya telah mengalami beberapa kali perubahan sehubungan dengan kebutuhan di negeri Belanda. ${ }^{36}$

Pada tahun 2004, seratus empat puluh empat tahun setelah Peraturan Jabatan Notaris dicanangkan, akhirnya bangsa Indonesia berhasil menyusun Undang-Undang tentang Kenotariatan, yaitu dengan dicanangkannya UndangUndang Nomor 30 Tahun 2004 tentang Jabatan Notaris yang kemudian disempurnakan dengan dikeluarkannya Undang-Undang Nomor 2 Tahun 2014 tentang Jabatan Notaris. ${ }^{37}$

Pengertian tentang notaris pertama kali dapat ditemukan pada Article 1 Notariswet (S.1860-3). ${ }^{38}$ Pengertian notaris tersebut diadopsi langsung oleh Peraturan Jabatan Notaris di Indonesia yang mulai berlaku pada tanggal 1 Juli 1860 yang jika diterjemahkan ke dalam bahasa Indonesia, ${ }^{39}$ selanjutnya dengan

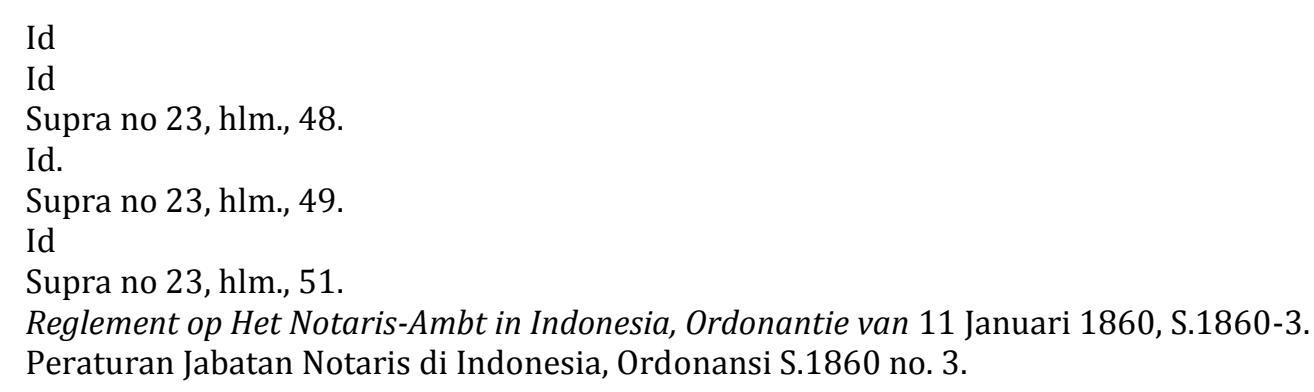


diberlakukannya UUJN maka definisi berbunyi: 40 "Notaris adalah pejabat umum yang berwenang untuk membuat akta otentik dan kewenangan lainnya sebagaimana dimaksud dalam Undang-Undang ini."

Pengertian tentang akta otentik sendiri diatur dalam Pasal 1868 KUH.Perdata yang berbunyi ${ }^{41}$ :

"Suatu akta otentik ialah suatu akta yang di dalam bentuk yang ditentukan oleh undang-undang, dibuat oleh atau di hadapan pegawai-pegawai umum yang berkuasa untuk itu di tempat dimana akta dibuatnya."

Notaris merupakan satu-satunya pejabat yang diberikan wewenang umum oleh Undang-Undang sebagai pembuat akta otentik. Semua pejabat lain yang memiliki wewenang sejenis, tidaklah memiliki kewenangan seluas kewenangan umum yang dimiliki oleh Notaris. Kewenangan pejabat lain hanya kewenangan tertentu dalam hal-hal yang dikecualikan oleh Undang-Undang, misalnya Aktaakta otentik yang dibuat oleh Pegawai Pencatatan Sipil dan Kependudukan.

Oleh karena itu, apabila dalam suatu perundang-undangan untuk suatu perbuatan hukum diharuskan adanya akta otentik, maka hal itu hanya dapat dilakukan dengan suatu akta notaris. Pengecualian untuk hal ini adalah jika oleh undang-undang dinyatakan secara tegas, bahwa selain dari notaris juga pejabat umum lainnya turut berwenang atau sebagai satu-satunya pejabat umum yang berwenang untuk itu.

Notaris sebagai seorang Pejabat Umum, diberi wewenang untuk membuat akta mengenai semua perbuatan, perjanjian dan penetapan. Perbuatan, perjanjian dan penetapan yang dimaksud haruslah yang ditetapkan oleh suatu peraturan umum atau oleh yang berkepentingan, dikehendaki untuk dinyatakan dalam suatu akta otentik. Salah satu akta otentik yang merupakan kewenangan notaris adalah Akta/Surat Keterangan Waris. UUJN tidak memberikan pengaturan yang tegas mengenai wewenang notaris dalam membuat Akta/Surat Keterangan Waris. Akan tetapi, pengaturan mengenai kewenangan notaris dalam pembuatan Akta Keterangan dapat disimpulkan dari Pasal 15 ayat (3) UUJN yang berbunyi:

40 Undang-Undang No. 30 Tahun 2004 tentang Jabatan Notaris.

41 Kitab Undang-Undang Hukum Perdata 
"Selain kewenangan sebagaimana dimaksud pada ayat (1) dan ayat (2), Notaris mempunyai kewenangan lain yang diatur dalam peraturan perundang-undangan."

Selain itu dalam Pasal 111 ayat (1) huruf c Peraturan Menteri Negara Agraria No. 3 Tahun 1997 yang merupakan pelaksanaan dari Peraturan Pemerintah No. 24 Tahun 1997 tentang Pendaftaran Tanah juga secara tegas diatur bahwa:

"Balik nama sertifikat ke nama ahli waris harus dibuat berdasarkan Akta/Surat Keterangan Waris yang dibuat oleh Notaris."

\section{Kewenangan Pembuatan Surat Keterangan Waris}

Dalam pembuatan Surat Keterangan Waris, seorang notaris menyusunnya berdasarkan keterangan pihak-pihak ahli waris serta dengan melakukan klarifikasi ke Daftar Pusat Wasiat Kementerian Hukum dan Hak Asasi Manusia terhadap kemungkinan adanya wasiat yang dapat berpengaruh dalam Surat Keterangan Waris yang akan dibuatnya tersebut.

Dalam masyarakat Indonesia yang sangat heterogen dewasa ini, perlu disadari bahwa notaris memang bukanlah satu-satunya pihak yang berwenang untuk membuat Keterangan Waris. Negara Indonesia masih menetapkan pihakpihak lain yang berwenang untuk membuatkan Keterangan Waris sesuai dengan golongan penduduk yang masih eksis di Indonesia. Namun demikian dari pemaparan tentang berbagai peraturan yang mengatur tanggung jawab dan kewenangan terhadap Notaris tampak bahwa Notaris belum dimungkinkan untuk melakukan pembuatan Surat Keterangan Waris bagi Masyarakat Adat (atau masyarakat yang tidak tunduk pada Hukum Perdata Barat).

\section{Peraturan tentang Penggolongan Penduduk}

Pemikiran yang masih mengkotak-kotakkan masyarakat ke dalam golongan-golongan seperti saat penjajahan Belanda dahulu, menurut Penulis bukanlah suatu pemikiran yang patut diterima. Pemikiran tersebut hanya membuat Bangsa Indonesia semakin terpecah-pecah dan sulit untuk maju. Keberadaan pihak yang ahli di bidang-bidang tertentu dalam masyarakat 
seharusnya dapat dimanfaatkan secara optimal, untuk itu, seharusnya para pembuat Peraturan Perundang-undangan dan juga para Notaris tidak menutup mata terhadap kebutuhan yang timbul di masyarakat (termasuk di dalamnya kebutuhan masyarakat adat).

Diundangkannya Undang-undang Kewarganegaraan pada tahun 2006 pun yang diharapkan dapat memberi angin segar bagi penghapusan golongan ternyata mempunyai misi yang sama sekali berbeda dengan penghapusan golongan penduduk. Pengelompokan penduduk Indonesia menjadi Warganegara Indonesia dan Warganegara Asing hanyalah ditujukan bagi kepentingan penentuan kewarganegaraan seseorang dan sebagai upaya untuk meniadakan kehadiran anak-anak dengan kewarganegaraan ganda ataupun tanpa kewarganegaraan. Meskipun penulis berharap banyak tentang penghapusan golongan dari undangundang ini namun fakta yang ada menunjukkan ketiadaan maksud untuk menghapuskan penggolongan penduduk sebagaimana yang diatur dalam Pasal 131 IS dan Pasal 163 IS di masa lalu. Oleh karena itu, diundangkannya undangundang tersebut ternyata tidak memiliki dampak sama sekali terhadap penghapusan golongan penduduk.

\section{Kebutuhan Masyarakat Adat Bali akan Kepastian Hukum}

Fakta menunjukkan kebenaran adanya keinginan dari berbagai lapisan masyarakat mengenai adanya suatu kepastian hukum terhadap permasalahan waris yang mereka terima. Hal ini tentu saja menjadi tantangan yang cukup serius sebagai seorang notaris yang memang memiliki keahlian dan networking di bidang tersebut. Selaras dengan hal tersebut, seharusnya pihak pembuat peraturan perundang-undangan juga lebih tanggap terhadap adanya kebutuhan masyarakat dengan mempersenjatai para notaris dengan peraturan perundang-undangan yang lengkap untuk dapat melaksanakan tugas bagi pihak-pihak selain dari pihak yang seharusnya dilayani oleh notaris selama ini dalam bidang masalah waris. Selain daripada itu, seharusnya lembaga-lembaga lain yang selama ini diberikan wewenang untuk hal tersebut juga lebih "legowo" dalam membaca kebutuhan masyarakat tersebut dengan melepaskan kewenangan mereka kepada pihak yang 
lebih kompeten atau bisa juga pemerintah berusaha meningkatkan kompetensi para pemegang wewenang tersebut dengan berbagai pendidikan dan pelatihan, sehingga para pemegang wewenang sesuai dengan pluralisme masyarakat yang ada tersebut bisa memiliki kompetensi dan networking "sekelas" Notaris. Namun demikian dalam hal ini yang menjadi pertanyaan adalah seberapa jauh kebutuhan Masyarakat Adat ini dapat menjadi pendorong bagi pembuat undang-undang untuk menerbitkan peraturan perundang-undangan yang dapat mengakomodasi kepentingan tersebut.

\section{Perubahan Pola Pemikiran Masyarakat Adat Bali}

Kebutuhan Masyarakat Adat Bali akan suatu kepastian hukum, menjadikan timbulnya suatu perubahan dalam pola perilaku Masyarakat Adat Bali. Hukum Adat, yang pada mulanya menyajikan segala sesuatu secara tidak tertulis, menjadi sasaran perubahan yang utama. Para Pemuka Adat di Bali mulai memikirkan caracara untuk menuangkan segala tindakan hukum yang dilakukan berdasarkan Hukum Adat ke dalam suatu bentuk tertulis. Di saat masyarakat adat mulai merasa membutuhkan sebuah figur yang keterangannya dapat diandalkan, dapat

dipercayai, yang tanda tangannya serta segel yang diberikan oleh figur tersebut akan memberikan suatu jaminan dan bukti yang kuat, juga suatu figur yang dapat memberikan perasaan aman karena keyakinan akan nasehat hukum yang tidak bersifat memihak serta jaminan rahasia dan keamanan atas informasi yang disampaikan, kehadiran notaris mulai menjadi suatu pertimbangan.

\section{Fakta di Lapangan}

Pada mulanya, masyarakat Adat di Bali masih sangat mengandalkan keberadaan Kepala Desa ataupun Kepala Banjar atau Kepala Adat untuk dapat membuatkan sebuah surat keterangan mengenai hal-hal yang bersangkutan dengan pewarisan, termasuk di dalamnya adalah surat keterangan waris. Namun dengan berjalannya waktu, dimana arus modernisasi semakin merambah dalam kehidupan Masyarakat Adat Bali, apalagi didukung dengan mulai lahirnya banyak kaum intelektual yang semakin menyadari mengenai pentingnya arti surat bukti 
dalam kehidupan mereka, mulailah timbul pertanyaan tentang keabsahan suratsurat yang dihasilkan oleh seorang Kepala Adat. Sejarah tentang latar belakang pewarisan menjadi suatu hal kompleks yang pada akhirnya banyak menimbulkan pertanyaan mengenai kadar kebenarannya. Hal ini bisa terjadi karena belum adanya suatu bukti tertulis yang bisa dijadikan pegangan yang utama. Kebenarannya hanya didasarkan pada pengetahuan dan pengalaman mereka. Hal tersebut sedikit banyak akan menimbulkan problem mengenai kepastian hukum di kemudian hari.

Perkembangan dalam masyarakat kemudian menunjukkan bahwa kebutuhan akan suatu bukti otentik, berkenaan dengan tindakan hukum berdasarkan Hukum Adat, semakin dibutuhkan oleh masyarakat yang tunduk pada Hukum Adat. Dalam kondisi demikian, sosok yang paling memenuhi syarat adalah seorang notaris. Paradigma pemikiran bahwa seorang notaris hanya boleh melayani pihak-pihak yang tunduk pada Hukum Perdata Barat atau pihak-pihak yang secara diam-diam menundukkan diri pada Hukum Perdata Barat, menjadi suatu pemikiran yang harus dipikirkan sekali lagi. Kemerdekaan Negara Republik Indonesia dan diakuinya keberadaan tiga sistem hukum dalam kehidupan rakyat Indonesia, menjadikan notaris yang diangkat oleh Negara sebagai seorang pejabat umum harus dapat berdiri di atas ketiga sistem hukum tersebut dan memberikan pelayanan hukum kepada seluruh Masyarakat Indonesia tanpa kecuali.

Kebutuhan yang ada dalam Masyarakat Adat Bali yang berkaitan dengan fungsi seorang notaris adalah antara lain dengan pembuatan sebuah Surat Keterangan Waris Adat. Adapun maksud dari Keterangan Waris Adat adalah merupakan suatu bukti otentik dalam pewarisan yang berdasarkan hukum waris adat Bali. Oleh karena itu dapat disimpulkan bahwa, yang diperlukan oleh masyarakat adat tersebut adalah adanya penuangan mengenai pihak-pihak yang berhak mewaris berdasarkan Hukum Adat Bali dalam suatu bentuk tertulis yang merupakan bukti otentik yang tak terbantahkan. Kebutuhan Masyarakat Adat Bali tersebut timbul sebagai antisipasi atas banyaknya permasalahan warisan yang timbul di Bali, karena seringkali melibatkan jumlah harta yang tidak kecil sehingga 
akhirnya menimbulkan masalah yang tidak kecil pula di antara para keluarga sedarah.

Adanya kebutuhan terhadap akta-akta pembuktian bagi Masyarakat Adat Bali mungkin tidak akan berhenti sampai pada Surat Keterangan Waris. Bukan tidak mungkin di suatu hari nanti akan dibutuhkan pula adanya akta-akta lainnya sekedar untuk sarana pembuktian yang dapat menekan timbulnya sengketasengketa keluarga yang berbuntut pada sengketa waris dalam Masyarakat Adat Bali.

Berbagai polemik yang beredar dalam kalangan Notaris mengenai bentuk dari Surat Keterangan Waris secara de facto, tidak menyurutkan kepercayaan masyarakat terhadap kekuatan pembuktian dari Surat Keterangan Waris itu sendiri. Hal ini mengingat tahapan yang dilakukan oleh seorang notaris (yang secara otomatis juga merupakan pihak yang telah cukup menerima bekal pengetahuan mengenai masalah pewarisan dalam pendidikannya atau dianggap sebagai pihak yang cukup mumpuni di bidangnya) dalam membuat suatu Surat Keterangan Waris berdasarkan keterangan para ahli waris. Adanya kepercayaan masyarakat yang sangat besar terhadap kekuatan isi Surat Keterangan Waris yang dibuat oleh seorang notaris sebaiknya dijadikan suatu katalisator bagi para notaris untuk bekerja lebih berhati-hati dan tidak menyia-nyiakan kepercayaan masyarakat yang telah diberikan kepada para notaris.

Berkenaan dengan keharusan para notaris untuk menyikapi kebutuhan dalam masyarakat adat tersebut, serta untuk tidak menyia-nyiakan kepercayaan masyarakat yang telah diberikan kepada para notaris, diperlukan adanya usahausaha untuk optimalisasi kapabilitas para notaris demi menyelaraskan kemampuan para notaris dengan kebutuhan dalam masyarakat. Hal ini sebaiknya dilakukan dengan pendalaman pengetahuan notaris dalam pengetahuan mengenai bidang-bidang yang bersangkutan dengan Hukum Adat.

Penelitian ini memang hanya dilakukan terhadap kebutuhan Masyarakat Adat Bali saja, namun bukan tidak mungkin masyarakat adat lain di seluruh Indonesia memiliki kebutuhan yang kurang lebih sama. Penulis juga telah melakukan berbagai telaahan atas berbagai pengaturan yang ada dalam Peraturan 
Perundang-undangan di Indonesia mengenai posisi seorang notaris sebagai Pejabat Umum yang diangkat oleh Negara. Dalam hal ini pada akhirnya akan dikembalikan kepada para notaris sebagai penyandang profesi pejabat umum ini. Sudah waktunya seorang notaris juga membuka pikirannya dan tidak menempatkan dirinya sebagaimana pada jaman penjajahan dahulu. Perlu diingat juga bahwa diangkatnya seorang notaris sebagai seorang pejabat umum oleh negara, menjadikan profesi notaris sebagai suatu jabatan yang harus berdiri di atas tiga sistem hukum dalam hukum waris yang diakui oleh Negara Indonesia. Dalam hal ini, Notaris harus menjadi suatu profesi yang memberikan pelayanan kepada seluruh lapisan masyarakat Indonesia yang membutuhkan jasanya sebagai seorang pejabat umum yang diangkat oleh Negara.

\section{Peran Notaris dalam Memberikan Kepastian Hukum}

Di Indonesia selama ini, keterangan hak waris secara rutin masih dibuat oleh para notaris. Keterangan yang dibuat oleh para notaris ini telah mendapatkan kepercayaan penuh dari masyarakat dan Lembaga Pemerintah, misalnya: Kantor Pertanahan, dapat mengetahui kepada siapa suatu harta tidak bergerak milik seseorang yang baru meninggal dunia telah diwariskan. Selain itu Bank yang menerima simpanan dana ataupun barang beserta surat-surat dalam safe deposit box milik almarhum, juga dapat mengetahui, siapa saja yang berhak untuk mengambil dana maupun barang-barang tersebut. Surat Keterangan Waris memberikan keterangan bagi masyarakat untuk dapat mengetahui dengan tepat dan pasti, pihak-pihak mana saja yang berhak atas harta peninggalan seorang pewaris.

Mengingat pentingnya arti dari sebuah keterangan waris dalam mengurangi resiko timbulnya keributan karena dilaksanakannya suatu tindakan hukum oleh orang yang tidak berhak, maka tidaklah mengherankan jika banyak pihak yang menginginkan adanya pegangan yang memberikan jaminan. Jaminan yang diinginkan di sini maksudnya adalah jaminan bahwa penyerahan atau pembayaran yang dilakukan oleh pihak yang pernah menerimanya dari pewaris telah dilakukan kepada pihak yang tepat. 


\section{Penutup}

Pemaparan di atas memperlihatkan bahwa kondisi perundang-undangan yang ada di Negara Indonesia saat ini, belum memungkinkan seorang Notaris untuk membuatkan Surat Keterangan Waris bagi pihak-pihak yang bukan merupakan pihak yang tunduk pada Hukum Perdata Barat, meskipun kondisi di masyarakat menunjukkan adanya kebutuhan yang cukup tinggi akan hal tersebut.

Sementara jika dilihat dari latar belakang historis dan sosiologis mengenai efektivitas keberlakuan sebuah peraturan perundang-undangan, cukup banyak peraturan perundang-undangan yang bisa efektif berlaku dalam waktu yang singkat karena dibuat berdasarkan apreasiasi masyarakat yang berhubungan erat dengan objek pengaturan dalam peraturan perundang-undangan tersebut. Seharusnya jika dilihat dari hal tersebut, adanya kebutuhan hukum dalam masyarakat yang dapat mendorong dibuatnya suatu peraturan perundangundangan, bisa menjadi suatu hal yang sangat efektif.

Hal terakhir yang perlu diberikan catatan juga bahwa jalan keluar yang dapat ditempuh oleh negara ini dalam rangka melegalisasi pelayanan notaris terhadap kebutuhan seluruh masyarakat dari berbagai golongan akan Surat Keterangan Waris adalah dengan membuat suatu peraturan perundang-undangan yang dapat mengakomodasi kebutuhan tersebut.

Besarnya kebutuhan masyarakat adat akan produk-produk yang hanya dapat dihasilkan oleh profesi notaris menelurkan suatu kebutuhan baru bagi notaris untuk belajar lebih banyak serta kebutuhan bagi para pembuat peraturan perundang-undangan untuk mulai mempersiapkan pembuatan peraturan perundang-undangan yang dapat melegalisasi kebutuhan tersebut. Untuk itu dalam rangka meningkatkan kinerja notaris untuk mendapatkan kepuasan bagi masyarakat adat pengguna jasa notaris, para notaris harus lebih dapat mengembangkan diri serta menambah pengetahuan dalam bidang-bidang Hukum Adat terutama dalam hukum waris adat di tempat dimana notaris tersebut bertugas. Hal tersebut diharapkan dapat mengakomodasi kepentingan masyarakat adat serta melestarikan Hukum Adat yang merupakan ciri keanekaragaman Bangsa Indonesia dalam suatu bentuk yang sesuai dengan perkembangan jaman. 
Diperlukan adanya suatu instrumen material yang berupa suatu produk peraturan perundang-undangan yang dapat menghapuskan penggolongan penduduk yang pernah diciptakan oleh pemerintah kolonial sehingga seorang notaris yang merupakan pejabat umum yang ditunjuk berdasarkan hukum Indonesia dapat memberikan pelayanan secara optimal kepada seluruh masyarakat Indonesia tanpa kecuali dan dapat melakukan tugas tersebut tanpa melanggar hukum materiil yang berlaku.

Jika ternyata pembuatan undang-undang yang akan menghapuskan golongan penduduk yang pernah diciptakan oleh pemerintah kolonial tersebut tidak dimungkinkan untuk dilaksanakan, maka sebagai gantinya, pemerintah mempunyai pekerjaan rumah yang lebih banyak lagi, yaitu memastikan bahwa pemerintah akan menunjuk para pejabat yang memiliki kompetensi setara notaris untuk dapat membuatkan Surat Keterangan Waris bagi pihak-pihak yang tidak tunduk pada Hukum Perdata Barat serta melakukan pembinaan secara terus menerus terhadap para pemimpin adat maupun pemimpin wilayah seperti camat, serta melaksanakan perbaikan sistem pendataan kependudukan sehingga semua data dapat diketahui secara online (termasuk di dalamnya kemungkinan akses data ke Daftar Pusat Wasiat). 


\section{Daftar Pustaka}

\section{Buku:}

B. Ter Haar Bzn, diterjemahkan oleh K. Ng. Soebakti Poesponoto, Beginselen en Stelsel Van Het Adatrecht, Pradnja Paramita d/h J.B. Wolters, Jakarta, 1960.

Bernard Arief Sidharta, Refleksi Tentang Struktur Ilmu Hukum, Mandar Maju, Bandung, 1999.

C.F.G. Sunaryati Hartono, Dari Hukum Antar Golongan ke Hukum Antar Adat, Alumni, Bandung, 1971.

Chidir Ali, Hukum Adat Bali dan Lombok dalam Yurisprudensi Indonesia, Pradnya Paramita, Jakarta, 1981.

Dijk, Van, diterjemahkan oleh Mr. A Soehardi, Pengantar Hukum Adat Indonesia Cetakan ke-3, Bandung, Penerbit Vorkink-Van Hoeve, Bandung's Gravenhage.

Friedmann W, Teori \& Filsafat Hukum Idealisme Filosofis \& Problema Keadilan (Susunan II), Rajawali Pers, Jakarta.

Gde Pudja, Hukum Kewarisan Hindu Yang Diresepsir Ke Dalam Hukum Adat Bali dan Lombok, CV Junasco, Jakarta, 1977.

, Pengantar tentang Perkawinan Menurut Hukum Hindu (Didasarkan Manusmriti, Mayasari, Jakarta, 1983;

H.R. Otje Salman Soemadiningrat, Kesadaran Hukum Masyarakat Terhadap Hukum Waris, Alumni, Bandung, 1993.

, Rekonseptualisasi Hukum Adat Kontemporer, Telaah Kritis terhadap Hukum Adat sebagai Hukum yang Hidup dalam Masyarakat, Alumni, Bandung, 2002.

H.R. Otje Salman Soemadiningrat dan Anton F. Susanto, Teori Hukum, Mengingat, Mengumpulkan dan Membuka Kembali, PT. Refika Aditama, Bandung, 2004.

I Gde Panetja, Aneka Catatan tentang Hukum Adat Bali, CV. Kayumas, Denpasar, 1986.

I Goesti Poetoe Djlantik, Wetboek Poerwa Agama, Landerukkerij, Batavia, 1918.

I Gusti Ketut Kaler, Butir-Butir Tercecer Tentang Adat Bali 1, Penerbit Bali Agung, Denpasar, 1983.

, Butir-Butir Tercecer Tentang Adat Bali 2, CV Kayumas Agung, Denpasar, 1994.

I Gusti Ketut Sutha, Bunga Rampai Beberapa Aspekta Hukum Adat, Penerbit Liberty, Yogyakarta, 1987.

I Made Suasthawa Dharmayudha dan I Wayan Koti Çantika, Filsafat Adat Bali, PT Upada Sastra, Denpasar, 1991.

Iman Sudiyat, Asas-Asas Hukum Adat Bekal Pengantar, Penerbit Liberty, Yogyakarta, 1978.

I Wayan Beni dan Sagung Ngurah, Hukum Adat di dalam Yurisprudensi Indonesia, Surya Jaya, Denpasar,1986.

Korn, VE, Hukum Adat Waris di Bali, terjemahan serta diberi catatan-catatan oleh I Gde Wayan Pangkat, Fakultas Hukum \& Pengetahuan Masyarakat Universitas Udayana, Denpasar, 1972. 
Lili Rasjidi, Dasar-Dasar Filsafat Hukum, Citra Aditya Bakti, Bandung, 1996.

Mochtar Kusumaatmadja, Hukum, Masyarakat, dan Pembinaan Hukum Nasional, Bina Cipta, Bandung,1976.

R. Soepomo, Bab-bab tentang Hukum Adat, Pradnya Paramita, Jakarta, 1983.

Rony Hanityo Soemarto, Metode Penelitian Hukum, Ghalia Indonesia, Jakarta, 1982.

Satjipto Rahardjo, Hukum dan Perubahan Sosial, Alumni, Bandung, 1979.

Soekanto, Meninjau Hukum Adat Indonesia, Penerbit Soeroengan Petjenongan 58, Jakarta, 1958.

Soerjono Soekanto, Kamus Hukum Adat, Alumni, Bandung, 1978. , Kedudukan dan Peranan Hukum Adat di Indonesia, Kurnia Esa, Jakarta, 1982.

, Beberapa Catatan Tentang Pembangunan Hukum, Majalah Hukum dan Pembangunan Undang-Undang No.1 Tahun 1974.

Subekti, Hukum Adat Indonesia dalam Yurisprudensi Mahkamah Agung, Alumni, Bandung, 2006.

Utrecht/Saleh Djindang, Pengantar dalam hukum Indonesia, PT Ichtiar Baru bekerjasama dengan Sinar Harapan, Jakarta,1983.

\section{Jurnal:}

Anak Agung Istri Ngurah Dyah Prami \& Nazrina Zuryani (2016). Perkawinan Antar Wangsa, Analisis Pewarisan dalam Adat Bali (Kajian Masyarakat Aktif Bali). Community Volume 2, Nomor 2, April 2016; ISSN; 2477-5746.

I Gede Surata (2019). Kedudukan Ahli Waris Predana Menurut Hukum Adat Bali Hubungannya dengan Hak Atas Tanah Terkait dengan Pesamuan Agung III Tahun 2010. Kertha Widya Jurnal Hukum Volume 7 Nomor 2 Desember 2019.

I Gusti Agung Ayu Putu Cahyania Tamara Buana (2018). Hak Anak Laki-Laki yang Berstatus Pradana Sebagai Ahli Waris Ditinjau Dari Hukum Adat Bali. Calyptra Jurnal Ilmiah Mahasiswa Universitas Surabaya, Volume 7, Nomor 1 Tahun 2018.

I Made Artana (2019). Kedudukan Harta Jiwa Dhana Menurut Hukum Adat Bali. Jurnal Yustitia Volume 13 Nomor 1 Tahun 2019.

Ni Luh Putu Darmini \& I Nyoman Lemes (2019). Kedudukan Anak Angkat dalam Hak Waris Ditinjau dari Hukum Adat Bali di Desa Depeha, Kecamatan Kubu Tambahan, Kabupaten Buleleng. Kertha Widya Jurnal Hukum Volume 7 Nomor 2 Desember 2019.

NI Nyoman Sukerti, Ida Bagus Putra Atmadja, IG.A. Mas Rwa Jayantiari, IG.A. Tirta Sari Dewi, IG.A. Bagus Agustya Pradnyana. Pewarisan Pada Masyarakat Adat Bali Terkait Ahli Waris Yang Beralih Agama. Acta Comitas (2016) 2:131-141; ISSN :2502-8960 I; e-ISSN: 2502-7573.

Ria Maheresty A.S., Aprilianti, Kasmawati (2018). Hak Anak Perempuan Dalam Sistem Pewarisan Pada Masyarakat Adat Bali (Studi di Banjar Tengah Sidorejo Kecamatan Sekampung Udik, Kabupaten Lampung Timur). Pactum Law Journal, Volume 1, Nomor 2 Tahun 2018. 
Warsita, I. P. A., Suwitra, I. M., \& ., Sukadana, I. K. (2020). Hak Wanita Tunggal terhadap Warisan dalam Hukum Adat Bali. Analogi Hukum. 2(1). 83-87. Doi: http://dx.doi.org/10.22225/.2.1.1628.83-87

\section{Peraturan Perundang-undangan:}

Undang-Undang Dasar Republik Indonesia 1945;

Reglement op Het Notaris-Ambt in Indonesia, Ordonantie van 11 Januari 1860, S.1860-3;

Peraturan Jabatan Notaris di Indonesia, Ordonansi S.1860 no. 3;

Kitab Undang-Undang Hukum Perdata;

Undang-undang Nomor 5 Tahun 1960 tentang Peraturan Dasar Pokok-Pokok Agraria;

Undang-undang Nomor 1 Tahun 1974 tentang Perkawinan;

Undang-undang Nomor 7 Tahun 1989 tentang Pengadilan Agama;

Undang-undang Nomor 39 Tahun 1999 tentang Hak Asasi Manusia;

Undang-undang Nomor 4 Tahun 2004 tentang Kekuasaan Kehakiman;

Undang-undang Nomor 25 Tahun 2004 tentang Sistem Perencanaan Pembangunan Nasional;

Undang-undang Nomor 30 Tahun 2004 tentang Undang-Undang Jabatan Notaris;

Undang-undang Nomor 32 Tahun 2004 tentang Pemerintahan Daerah;

Undang-undang Nomor 12 Tahun 2006 tentang Kewarganegaraan;

Undang-undang Nomor 17 Tahun 2007 tentang Rencana Pembangunan Jangka Panjang;

Peraturan Pemerintah Nomor 24 Nomor 1997 tentang Pendaftaran Tanah;

Peraturan Presiden Nomor 7 Tahun 2005 tentang Rencana Pembangunan Jangka Menengah Nasional Tahun 2004-2009;

Peraturan Menteri Agraria Nomor 3 Tahun 1997 tentang Ketentuan Pelaksanaan Peraturan Pemerintah Nomor 24 Nomor 1997 tentang Pendaftaran Tanah;

Peraturan Daerah Provinsi Bali Nomor 3 Tahun 2003 Tentang Perubahan Atas Peraturan Daerah Nomor 3 Tahun 2001 Tentang Desa Pakraman.

\section{Sumber dari Internet:}

http://www.indonesia.go.id/id - REPUBLIK INDONESIA

http://www.hukum-online.com

http://www. kennywiston.com/artcmarc77.doc

http://www.ejournal.unud.ac.id/abstrak

http://www.puspasca.ugm.ac.id/files

http://www.prakarsa-rakyat.org/artikel

http://www.forum.detik.com/archive

http://www.bphn.go.id/index.php?action=activity\&type=Seminar\&id=20080328 09391328

\section{Lain-lain:}

I Nyoman Nikanaya, 2007, Materi Pembinaan Prajuru Desa Pakraman, Dinas Kebudayaan Propinsi Bali; 
Jan Michiel Otto dalam pidato pengukuhannya sebagai Guru Besar yang berjudul: Reele rechtszekerheid in onwikkelingslanden, Universiteit Leiden, 2000 sebagaimana diterjemahkan oleh C.F.G. Sunaryati Hartono

Tim Penelitian dan Penulisan Hukum Adat Waris, Penelitian Hukum Adat tentang Warisan di Wilayah Hukum Pengadilan Tinggi Denpasar, Laporan Penelitian, Proyek Penelitian Hukum Adat Mahkamah Agung, 1990; Wawancara dengan beberapa tokoh Masyarakat Adat Bali. 